\title{
ФІЛОСОФСЬКИЙ АСПЕКТ ДУХОВНОСТІ: ПРОБЛЕМА ЦІННІСНИХ ОРІЄНТАЦІЙ
}

\section{Ю.Т. Василенко, О.Ю. Сільвестрова}

Сучасна інфляція людських цінностей стала реальним фактом: дегуманізація суспільного життя, переведення безпосереднього спілкування людей через засоби масової комунікації у дедалі більш опосередкований модус, всезагальний нігілізм та критицизм, фальш на всіх рівнях суспільно-політичного та економічного життя, відчуження сутності людини. Саме цим зумовлена підвищена увага до філософсько-історичного осмислення цінностей суспільства та особи, яке повинно включати в себе основні цілі та завдання породжені конкретною практикою, а також вимогу всебічного і об'єктивного аналізу всього знання про історичне буття.

Зазначену у назві статті проблему ми спробуємо розглянути крізь призму смислу і співвідношення категорій «філософія», «духовність», «культура», «гуманізм», «аксіологія», «особистість» тощо. Які ж соціальноісторичні процеси відображаються через їх зміст, і що кожен із нас вкладає в їх сутність? Як визначити, що їх вибір був правильним із позицій сучасності? I чи в майбутньому людина не буде жалкувати за цим вибором? Чи можемо ми бути впевнені у тому, що наші нащадки не пред'являтимуть нам свої претензії, як ми пред'являємо нашим попередникам? Наскільки наше розуміння духовних цінностей є адекватним соціальноісторичній ситуації, у якій перебуває людина?

На ці та інші запитання можна дати відносно вичерпну відповідь, якщо враховувати основних носіїв суспільної свідомості- конкретних людей. Без них всі наші запитання - порожні. Тому суспільна свідомість, а значить, і їі філософсько-історичний аспект, здатні існувати і повноцінно функціонувати не лише в суспільному, але й в індивідуальному, тобто через індивідуальну свідомість, яка виступає багатобарвною і одночасно

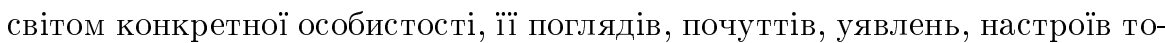
що. Знеособлене ж суспільство - це суспільство дегуманізоване. Саме вза-

Актуальні проблеми духовності

(Відп. ред.: Я.В. Шрамко)

Кривий Ріг (2005), 22-29 
ємозв'язок основних критеріїв гуманності вчинків із механізмом взаємодетермінації філософії та культури сприяє з'ясуванню сутності агресивних настроїв у сучасному світі, а також героїзації насильства, жорстокості, антигуманності тощо. Будь-який наш вчинок може бути «забарвлений» як у добро, так і у зло, моральність чи аморальність, цивілізацію чи варварство, культуру чи антикультуру тощо.

Одразу ж виникає наступне запитання: але ж ані добро, ані зло не можуть виступати наперед визначеними, а тому й не реалізуються автоматично? Вибір їх залишається за конкретною людиною чи частиною суспільства. Вони залежать також і від нашої здатності ставитися до самого себе, до свого життя об'єктивно; від готовності особи вирішувати як власні моральні завдання, так і хоча би моральні проблеми частини людства. Нарешті, вони залежать від нашої мужності бути самим собою, бути та існувати не лише для себе, а також і для інших. Проблема конкретноісторичного індивіда проявляється на рівні розуміння ним свободи, якої йому вдалося досягти. Людина з відносно пробудженою свідомістю, яка реалізує власно-обмежені можливості, виступає вільною, тому що може жити дійсним і навіть уявно-дійсним життям, при якому вона сама $є$ їі джерелом [6, с. 204]. Тому питання про критерії духовних цінностей - не лише про якісь їх аспекти, але й про культуру, про філософію, на яких можна «заземлити» протилежно-суперечливі морально-етичні концепції-є досить складним.

Основні цінності XX-XXI ст. у своїй сутності визначилися і визначаються глобальними загрозами, що нависли над майбутнім людства та його духовністю. Це, зокрема, знайшло своє відображення в ряді концепцій про «завершення історії», «знищення філософії», «виродження духовності», «незліченні кризові ситуаціі», у яких постійно перебуває людський розум, про заперечення будь-якого наукового знання щодо історичного процесу та його сенсу тощо. Ось чому зацікавленість проблемою духовності у їі історико-філософському та культурологічному аналізі, на нашу думку, є логічною. І знову-таки постає нове запитання: що покоління людей XX і XXI ст. (і не лише європейське) вкладає у розуміння сутності духовності, інтелектуальності, розуму тощо, і чи не вичерпують зазначені поняття основні характеристики духовної та матеріальної культури? Навряд чи хтось спробує дати однозначну відповідь.

Із нашої точки зору, дати вірні діагнози у співвідношенні інтелектуальності й духовності в системі культури чи філософії просто неможливо без одночасної їх кореляції із такими характеристиками культури, як пізнавальні, екзистенціальні, герменевтичні, феноменологічні та інші. Сфера духовного життя суспільства та людини охоплює всі форми інтелектуального життя в їх загальності та конкретності. Не може бути такої сфери індивідуальної, групової чи загальнолюдської діяльності, в яких так чи 
інакше не виявлявся людський дух, як своєрідний синонім людської свідомості у всій багатообразності якісних змін.

Відомо, що основні етапи розвитку людини та культури виступають зовнішньо схожими, а тому їх можна умовно називати не лише «епохами піднесення», але й «епохами згасання», коли настає фактичне чи уявне розчарування. Все залежить від конкретно-історичної ситуації. Мабуть, основним у «епохах згасання» виступає своєрідний присмак руйнування гармонії цілого й зрозумілого, тобто втрата ідеалів та внутрішня спустошеність, руйнування традиційно-застиглої соціальної картини світу, яка здавалася непорушною. Саме тут беруться під сумнів і гостро (часто без будь-яких підстав) критикуються наріжні догми, спростовуються класичні канони та основи, «поринають у небуття» образи і сенси розуміння минулого і сучасного, а тим часом «інше», яке часто безпідставно називають «новим», ще не сформувалося, лише проявляється, як «неосновне» чи його елемент. У такі періоди індивід із особливою гостротою відчуває, що він не може навчитися забуттю і що він на все життя «прикутий» до величезного тягаря минулого [3, с. 15]. Чи не означає це, що людина, свідомо чи несвідомо, прагне прийняти один бік зазначеної домінанти? Але ж їх може «набратися» декілька? На нашу думку, це означає, що буття сучасної людини, за всієіі її нелінійності, $є$ суперечливим та хаотичним, а тому не може бути зведене лише до суспільного.

Суспільні цінності формуються поступово, як відбір певних видів поведінки і досвіду людей. Ціннісний тип світорозуміння зумовлений суспільним способом життя людини, існуванням суспільних потреб. Завдяки соціальним потребам людина у своїй життєдіяльності могла керуватися образом належного, потрібного, але ще не наявного співвідношення речей. Завдяки цьому цінності формували особливий світ духовного буття, що підносив людину над реальністю. Із розвитком суспільства і його структуруванням, поглибленням духовності людини, ускладнювалося і ціннісне світосприйняття. Ціннісні виміри допомагають людині будувати соціально привабливий світ можливої дійсності, підносячи його над буденністю. Все це дає змогу усвідомити дві площини реальності-наявну та ідеальну, співвідносити їх, розглядаючи ідеальний світ як взірцевий щодо реального. Так суспільні цінності, виростаючи із реальних суспільних потреб, набували ідеалізованих рис. Цим і пояснюється їх складна суб'єкт-об'єктна природа.

Тому складний і суперечливий процес функціонування суспільних відносин та їх розуміння об'єктивно обумовлює зростання ролі суб'єктів цих відносин і необхідність постійного пошуку оптимальних зв'язків та відображення їх збагачення духовного життя суспільства. Об'єктивні причини, що актуалізують духовне життя суспільства, сьогодні постійно набувають нетрадиційного вирішення, особливо через процес відродження 
національних культур, власної духовності, наближення до європейських чи загальнолюдських цінностей на основі інтеграції життя різних народів; зростання якісних характеристик духовності, культури, мислення, свідомості, виховання духовних основ та реалізації потенціалів особистості й переосмислення класичних парадигм розвитку духовного життя конкретного суспільства й усього людства тощо.

Яким же є зміст духовного життя суспільства у минулому і в наш час? Варто зауважити, що духовне життя суспільства виступає надзвичайно широким поняттям, яке включає в себе усю багатогранність процесів, явищ, що пов'язані з духовною сферою різноманітної життєдіяльності людей. Одночасно це і сукупність ідей, поглядів, почуттів, уявлень людей, процес їх виробництва. Постійно перебуваючи у «полоні» багаточисельних духовних цінностей, особа через своєрідне «вмонтування» до них прагне перевести суспільні ідеї у свій внутрішній світ. Фактично у своїй основі духовне життя суспільства охоплює світ ідеального разом із його носіями - соціальними суб'єктами (індивідами, народами, етносами). При цьому ціннісні орієнтири буття постійно змінюються, трансформуються, впливаючи на спосіб осягнення соціального і природного світу.

По мірі розвитку індивідуума і суспільства їх духовність стає все більше концептуальною і систематизованою при підвищенні рівнів інформованості та утилітарності. Але одночасно відбувається і процес втрати якостей (внутрішніх чи зовнішніх) та власних духовних цінностей. Не випадково духовність, що формується в об'єднуючій діяльності людей, здійснює своєрідний та величезний вплив саме на вибір іï, на розстановку акцентів зсередини та їх диференціацію. Ось чому ми розглядаємо процес формування та реалізацію ідей в ході соціальної діяльності та вплив їх на змінність, що проявляється у діяльності, з якої вона породжується. Виникнення ідей пов'язано з поясненням традицій, а завершення їх настає тоді, коли відкриваються і розвиваються нові методи та інститути [4, c. 498].

Ціннісна свідомість сприяє творенню власного світу, світу емоційних переживань, ціннісних образів. У ціннісній формі людина не об'єктивує, а суб'єктивує зовнішню дійсність, привласнюючи її, наділяючи людськими смислами, стверджуючи тотожність із собою. Тому цінністю є лише те, що усвідомлюється, переживається як цінність.

Світ цінностей - це світ саме конкретно-практичної діяльності. Наше емоційне ставлення до явищ зовнішнього буття, їх оцінка здійснюється у практичному житті. Для ціннісної свідомості важливим $€$ те, яке значення має предмет для нас. У житті індивіда вищі цінності визначають сенс його існування, цілісність особистості, забезпечують процес самотворення.

Людське існування в його історичному змісті за своєю суттю є процесом формування і утвердження цінностей. Людське життя поєднане із 
необхідністю постійно робити вибір, а це зумовлює появу системи цінностей. Джерелом цінностей не $\epsilon$ ні емоційна сфера свідомості, ці щось емпіричне, ні трансцендентне. Вони $є$ феномени, які самовільно проектуються людиною, $є$ результатом рішень, які приймають люди. Ніхто своїм впливом не може примусити людину визнати цінність, якщо вона сама не визнає १ї такою.

Суспільство є тим середовищем, де формуються та існують цінності. Світ цінностей, із яким ми постійно зв'язані, $є$ наслідком як колективної, так і індивідуальної творчості. Цінності в житті суспільства виступають соціально-значимими орієнтирами діяльності суб'єктів, одним із факторів розгортання історії, виконуючи роль інтегруючих, соціалізуючих, комунікативних засад, забезпечують духовно-вольову єдність суспільства.

Саме тут вся наша духовність своєрідно «розмелюється» на власні частини, нерідко однохвилинні, своєрідні уламки, які використовуються у конкретних цілях. Особа виступає чи не єдиною істотою у світі, яка не може постійно не прагнути стати людиною. Фактично від народження, сама по собі, людина спочатку виступає «нічим» через свою природну незавершеність та залишеність. «Щось» у ній «з'являється» вже із початком присвоєння «неприродного» світу, а в своїй сутності того предметносмислового й ціннісного Всесвіту, який повинен стати «людським» і навіть «надто людським», який пов'язаний, найперше, з раціоналізмом. Постійне «занурення» у світ та захопленість тим, що в «людині є від людини», призводить врешті-решт до інтерпретації самого розуміння «природності».

Ось чому здатність до самостійного осмислення і власного вибору виступає важливою умовою соціально-філософської історичності у розумінні духовності. Подібна здатність має у своїй основі неперехідний характер, хоча і виявляє себе в різних історичних ситуаціях, мірах та формах. Фактично вони постійно перебувають у невід'ємних атрибутах людської екзистенції, зокрема, таких, як свобода та неповторність. Саме це спонукає людину не зупинятися у своєму розвиткові, прагнути до того, чого ще немає, але що може і повинно з'явитися, «бути вірною собі, обирати саму себе», тобто «трансцендентувати від себе як емпіричної індивідуальності до себе, як самобутньої самості» [2, с. 301].

Відтак, необхідно своєрідно (але й відносно повно) «зануритися» у духовний світ свого часу, а не прагнути «вирватися» з нього, спробувати через себе збагнути основні «світові таїнства», замість спроб зосередження лише на своїх внутрішніх «секретах». У цьому ми вбачаємо основний зміст духовної доброчесності конкретної людини, частини суспільства чи всього людства.

У цих умовах ситуація існування, коли воно розглядається через духовність, має своєю передумовою таке мислення (тобто фактично філо- 
софію), де думка виступає первинною вірогідністю, де мислення є невідокремленим від розуміння, почуттів і споглядання конкретної людини. Той, хто постійно здійснює «безконечний рух віри», має в своїй основі те, щоб знайти самого себе і знову заспокоїтися у самому собі. В подібних умовах, зрозуміло, відносного самоздійснення не може відбуватися рух з огляду лише на проблеми власної відповідальності. Це має бути діалектичний процес вічного «подвійного» та «подвійності», в якому традиції, ідеологія, віра у майбутнє «наступне життя» повинні поєднуватися з власними уявленнями про щастя у цьому новому світі. I, найперше, вірою у здійснення подібного хай і відносно-ілюзорного розуміння шастя.

Постійно перебуваючи у «подвійному» (чи багатомірному) стані, людина інколи виявляє здатність примусити себе пливти «проти течіі». Саме феномен «подвійності руху» у духовному самоздійсненні людини й призводить до самоствердження та життя її у суспільстві. «Нескінченне самозречення - це остання стадія, яка безпосередньо передує вірі: отже, жоден з тих, хто не здійснив цього руху, не має віри й тому, що лише в нескінченному самозреченні я стаю зрозумілим для себе самого в моїй одвічній значущості. I лише тоді може йтися про те, щоб осягнути наявне існування силою віри» $[1$, с. 34$]$. Ось чому наші уявлення про рух людської душі можна кваліфікувати як спробу осягнення хоча би однієї 3 форм духовного досвіду.

Саме на початку ХХ ст. М.Шелер і спробував визначити людське буття через категорії «дух» та «духовність» і таким чином «відкрити світ», «перевершуючи себе і свій світ» [8, с.149-151]. Проте, сучасна людина раптово стала обдуреною різними примарами. Реально вона віднайшла у собі нечувану жорстокість, моральність сліпого дикуна, вишуканість та вдосконаленість у тортурах та вбивствах. Ще О.Герцен передбачав нашестя «Чингізхана з телеграфами». Це його парадоксальне передбачення виправдалося у такому масштабі, який він і не міг уявити. Як це не прикро, більшість «нових Чингізханів» та їх послідовників зародилася в надрах Європи, і навіть сьогодні вони погрожують знищити людство [5, c. 407]. Суспільство буквально захлинув потік наївних та екстравагантних реформаторських соціально-економічних, політико-новаційних та інших проектів чи передбачень.

Чому ж «науки про дух» відмовляються від послуг дійсно наукових програм розвитку духовності суспільства, якими природничі науки у своїй царині успішно справляються? Мабуть, все залежить від системи світоглядно-ціннісних орієнтацій людини та конкретних завдань суспільства. Адже в кожному соціальному середовищі формуються і обумовлюються типи, характери, які так чи інакше розкриваються й вирішуються через філософсько-історичне їх пояснення. 3 цієї точки зору помилково вважати, що суспільна свідомість більше зацікавлена минулим, яке вичерпує- 
ться лише простим (точніше, тимчасово-вигідним) поясненням. У дійсності минуле і сучасне виступають межею нашої свідомості, де концептуалізується зв'язок між усіма модальностями часу: минулим, теперішнім і майбутнім. Сучасність не може бути повністю пізнана без звернення до минулого. Однак у рівній мірі її неможливо осягнути і без звернення до майбутнього, тобто без знання елементів майбутнього у теперішньому.

Ось чому суще виступає духовним містком, що веде людину з минулого у майбутнє. Прихована сутність суспільства не має в собі такої сили, яка б була в змозі здійснити опір відважному пізнанню, вона з часом розкривається перед людиною і дає їй насолоду спілкування. «Достойне співвідношення між иіннісним універсалізмом і иіннісним індивідуалізмом зберігається тоді й тільки тоді, коли кожен індивідуальний моральний суб'єкт ціною лишень йому знаних мук знаходить свої цінності, аж ніяк не втрачаючи з поля зору віхи морального й культурного розвитку, а також загальновизначені цінності. Це стосується не лише окремих індивідів, але й так званих колективних духовних індивідів. Тобто звідси випливає важливий висновок: ані повнота будь-якого культурного чи національного типу моральних життєвих ідеалів, ані їхня різноманітність жодною мірою не є аргументом проти об'єктивності моральних цінностей: це зумовлено тим, що тільки у спільному спогляданні та взаємопроникненні загальнозначимих та індивідуальнозначимих моральних цінностей ми досягаємо повної очевидності добра-в-собі [9, с. 28-29].

Маятник на шкалі соціально-духовних цінностей розгойдується 3 неймовірною силою, а тому розмірковувати про морально-психологічні цінності рівноваги досить важко. Пошуки вищих цінностей життя, схиляння перед чужими ідеалами часто не дають бажаного результату, тому що будь-який ідеал можна з часом спростувати. Які риси будуть переважати у цьому процесі? Пасивність чи відчай, терпимість чи мрії, сприйняття соціальної реальності чи її заперечення тощо, а можливо, тотальне збурення, яке буде протиставлене будь-якому обману, ідеологічній брехні, нігілізм чи скептицизм - ніхто не скаже остаточно.

Відсутність міри проявляється як в оцінках супротивників, так і в захопленості самобичування, а тепер й у поливанні брудом власного минулого, яким би кривавим воно не було (але це наше минуле і його ми повинні вивчати, враховувати, а не засуджувати чи огульно критикувати). Тому лише через «етичний компас» соціально-історичного аналізу ми можемо чогось досягнути в періоди своєрідного перекликання епох. Кожен із нас не може бути чистим аркушем паперу, на якому історія пише свої письмена, бо ми виробили у собі специфічну реакцію на вплив зовнішніх умов. Якби людина адаптувалася до них, то шляхом зміни обставин, власної природи, вона б автоматично пристосовувалася до таких умов, що б й призвело лише до пристосування. Людська еволюція в історії 
засновується на поєднанні різних стійких та тимчасових якостей постійних пошуків [7, с. 35].

Унікальність сучасного періоду історії (як і всіх попередніх) полягає у змінах ставлення не лише до природи, але й до історії, у прискоренні динаміки соціальних процесів і в удосконаленні різних суспільних стосунків, у перетворенні процесів, що відбуваються у світі, на глобальні, в нових орієнтаціях у поглядах на світ, на нові цінності, на питання «Як жити і як виживати?» Ось чому ми лише наголосимо на тому, що якщо переможе праця і справедливість, то буде врятований і світ, а також і ми в ньому.

\section{1 Бібліографія}

[1] Къеркегор С. Страх и трепет. - М., 1993.

[2] Мамардашвили М. Как я понимаю философию.-М., 1990.

[3] Соловъев Э.Ю. Прошлое толкует нас.-М., 1991.

[4] Стародубиева Л.В. Архітектура постмодернізму: Історія. Теорія. Практика. - К., 1998.

[5] Уайтхед А. Избранные работы по философии: Пер. с англ.-М., 1990.

[6] Франк С.Л. Духовные основы общества. - М., 1992.

[7] Фромм Э. Психоанализ и этика. - М., 1993.

[8] Шелер M. Положення людини в космосі // Читанка з історії філософії: У 6 кн. - Кн.6.: Зарубіжна філософія ХХ ст. / Під ред. Г.І. Волинки. - К., 1993.

[9] Шелер M. Сутність моральної особистості // Сучасна зарубіжна філософія. Течії і напрями. Хрестоматія. - K., 1996. 